\title{
Assessment of the Educational Process for Risk Management in the Canton Santo Domingo de Heredia, Costa Rica
}

\author{
Mario Fernández Arce, Marianela González, and Silvia Camacho Calvo
}

\section{ABSTRACT}

The educational process for Risk Management (GR) in the canton Santo Domingo de Heredia was evaluated by investigating the training activities carried out by different entities. These entities are: The National Commission for Risk Prevention and Emergency Attention (CNE), the Municipal Emergency Committee, 8 district emergency committees, Emergency Committees of public institutions and 8 elementary schools, one per district. In the studied area there are hazards and vulnerabilities that demand proper education in order to manage efficiently the probability of human and material loses. The educational process for risk management has been carried out in the chosen zone but its level or depth is unknown. The purpose of this work is to find out the state of education to prevent disaster or emergencies and improve its weak aspects. To obtain the required information, seven instruments (questionnaires) were applied to the following key actors: an official of CNE, the coordinators of Brigade or Committees of Emergency (4 different questionnaires), and finally the person who teaches about natural and technological events in each one of the selected schools. According to results, the population of Santo Domingo has not been adequately trained to properly face the dangers and reduce the vulnerability of the canton.

Keywords: Education, capacitation, preparation, hazards, risk.

\author{
Published Online: June 25, 2021 \\ ISSN: $2736-4534$ \\ DOI :10.24018/ejedu.2021.2.3.77 \\ Mario Fernández Arce* \\ Escuela de Geografía, Universidad de \\ Costa Rica, Costa Rica. \\ (mario.fernandezarce@ucr.ac.cr) \\ Marianela González \\ Escuela de Administración Educativa, \\ Universidad de Costa Rica, Costa Rica. \\ (Marianela.gonzalez@ ucr.ac.cr) \\ Silvia Camacho \\ Escuela de Administración Educativa, \\ Universidad de Costa Rica, Costa Rica. \\ (silvia.camachocalvo@ ucr.ac.cr)
}

*Corresponding Author

\section{INTRODUCTION}

The state of the educational process on risk management was evaluated in the canton, Santo Domingo de Heredia (Fig. 1) to find out the population's level of preparation to handle the disaster risk. That activity implied investigating the educational and training activities carried out by the Municipal Emergencies Committee (MEC), the Local (district) Emergencies Committees, the emergency brigades or risk management committees of public institutions, and the National Commission for Risk Prevention and Attention of Emergencies (CNE) in the studied area. Teaching about hazards, vulnerabilities, and risks in the schools of the canton was also investigated as well as the training on risk management received by the civil society.

The hazards [1]-[6] and vulnerabilities [7], [8] of Santo Domingo (canton) require education to manage the associated risk. The educational process for risk management must be measured to improve and strengthen it. Education is an alternative that allows people to explore and create an open process that prepares individuals to address the realities they face. The intended evaluation is useful to assess the progress of the Santo Domingo's society in education and preparation to manage the risk. The results would be helpful to fill the knowledge gap and improve the educational strategy of the emergency committees of the Municipality, public institutions, and schools.

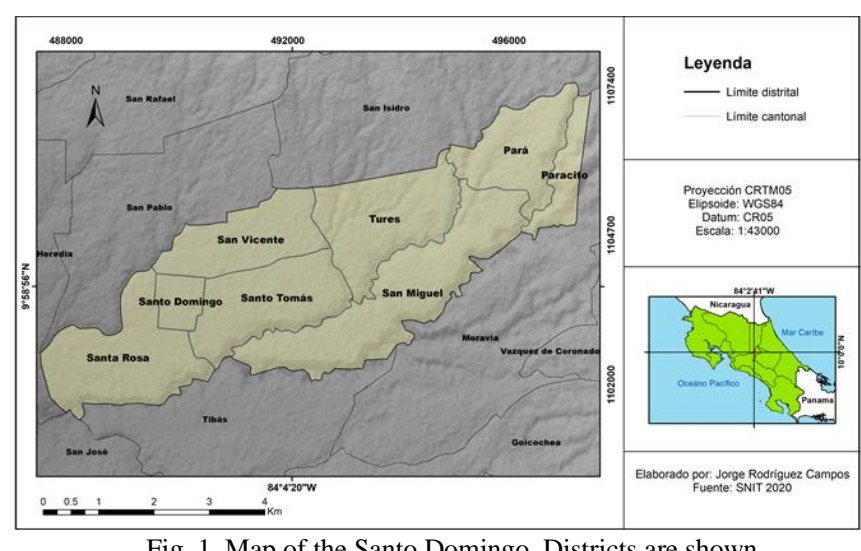

Fig. 1. Map of the Santo Domingo. Districts are shown.

The investigators elaborated 7 instruments to know the training activities carried out by the CNE, the Municipal Emergency Committee, the Local Emergency Committees, and the committees of public institutions. One questionnaire was applied to the person who teaches on risk management in 
schools and another to the person in charge of the School Emergency Committee. Around 10 people per district were interviewed to learn about the courses on risk management that the canton's population received in the last three years before the project.

According to the results, the $\mathrm{CNE}$ has been supporting the Municipal Emergencies Committee with training courses. All training activities are basic and focused on the response to impact of hazards. Civil Society receives little information to manage the risk.

\section{Methodology}

The research group chose a school per district to carry out the study and the committees that should be consulted. The selected schools were: Rubén Darío of Santa Rosa, Felix Arcadio Montero of the Central district, the school of San Vicente, the school of Santo Tomás, the school priest Ricardo Salas Campos of San Miguel, San Luis Gonzaga of Pará, Apolinar Lobo Umaña of Paracito and Cristobal Colón of Tures. An assistant coordinated the visits to the schools to explain the project and an investigator visited the person in charge of the local and institutional committees.

The researchers then conducted a documentary review to contextualize the project. The investigative process recovered information from various techniques and instruments, which included the review of the following documents: Safe School Challenge of CNE, the Strategy for Risk Management of the Education Sector of the Republic of Costa Rica (SRMESRCR), the UNICEF School Safety Index, the Sendai Framework for Disaster Reduction, the Costa Rican Risk Management Policy and the Costa Rican Risk Management Plan.

After that, seven instruments were designed to assess the state of education for risk management in the study area. The field work started in the schools where an investigator interviewed members of the school staff, particularly the person in charge of teaching risk management and also the coordinator of the Emergency Brigade or Committee. The main objective of the work in schools was to obtain information on teachers training proposed by the Strategy for Disaster Risk Management in the Education Sector of the Republic of Costa Rica [9] and by the Costa Rican Risk Management Plan [10]. The required information also included the use of the School Safety Index of UNICEF [11].

Simultaneously, the investigators searched for information in the 9 local emergency committees of the canton to find out the amount and content of the training courses received by the committee's members or those received by members of the community. The same information was collected in the committees of public institutions. A questionnaire was applied to people from each district of the canton to know the access to information on risks, perceived hazards, the causes of the known threats and the preparedness to face them.

The collected information was systematized and transferred to graphs, charts, and maps to have a better idea of the educational process for risk prevention in the Santo Domingo area.

\section{RESUlTS}

\section{A. Preparedness in Schools}

According to the professors who teach on risk management in the selected schools, only $50 \%$ of them have been trained to transfer knowledge properly. They consider that teaching on risk management is an easy and attractive task. Only one of all those consulted said that such work is difficult. Based on the opinion of the coordinators of the emergency committees, the training received by the personnel of the schools is focused on first aid and the use of fire extinguishers.

Data collected reveals that the elementary schools investigated do not use the School Safety Index - SSI [11] created by UNICEF to protect students, teachers and the administrative population. The interviewees stated that they do not even know such guide. However, they know and apply the CNE guide [10] to elaborate risk management plans. In fact, all centers have a plan that is updated every year. However, the people in charge of those plans are not sure they are good and effective. According to the interviewees, the priorities of the plans are training (fire extinguishers), emergency care, drills, state of the infrastructure, evacuation routes, institutional diagnosis, and protection of the school's population.

\section{B. Preparedness in Public Institutions}

Education, training and preparation for risk management were investigated in public institutions. The visited entities were: Banco Nacional de Costa Rica (National Bank of Costa Rica), Caja Costarricense del Seguro Social (the Social Security Institution of Costa Rica), Banco de Costa Rica (Bank of Costa Rica), Ministry of Health and Banco Popular (Popular Bank). The latter did not respond to the request and therefore, did not provided information.

The results suggest that so far, the courses received in these institutions are: first aid, fire principles, fire management, damage assessment (DA) and the incidents command system (SCI). Professionals from the Hugo Fonseca Clinic reported that they have received courses in cardio-vascular breathing, stretcher, bandaging and vertical rescue, very typical courses of the health area. Simulations, drills and signaling are practical actions carried out in most of these institutions to respond after the hazard's impact.

\section{Education promoted by Local Emergency Committees}

The Municipal Emergency Committee (MEC) has managed courses on disaster management (DM), damage assessment and incident command system. The DM, DA and the ICS courses have been exclusively for members of the Municipal Emergency Committee. According to the information obtained, the MEC has not received support from student programs in the 2016-2019 period, as proposed by the SRMESRCR. None of the 8 district emergency committees were active by the time of the study; therefore, it was not possible to determine if these committees imparted courses for the community during the 3 years before the study.

The CNE officer in charge of Santo Domingo reported that she managed 7 courses for the MEC in the last 3 years prior to the investigation related to this work. Those courses are: Operating Procedures of the Municipal Emergencies Committees, Supply Management, Disasters Management, 
Management of communications, Incident Command System and Damage Assessment. All these courses were exclusively for members of the MEC. The information provided by both the Coordinator of the MEC and the CNE's Officer coincide regarding the courses carried out by $\mathrm{CNE}$. According to that information, MEC requests the courses to the $\mathrm{CNE}$ and $\mathrm{CNE}$ responds offering basic courses to MEC.

\section{Preparedness to the Civil Society}

People from each district were interviewed to know the level of education on risk management of the Civil Society (Fig. 2).

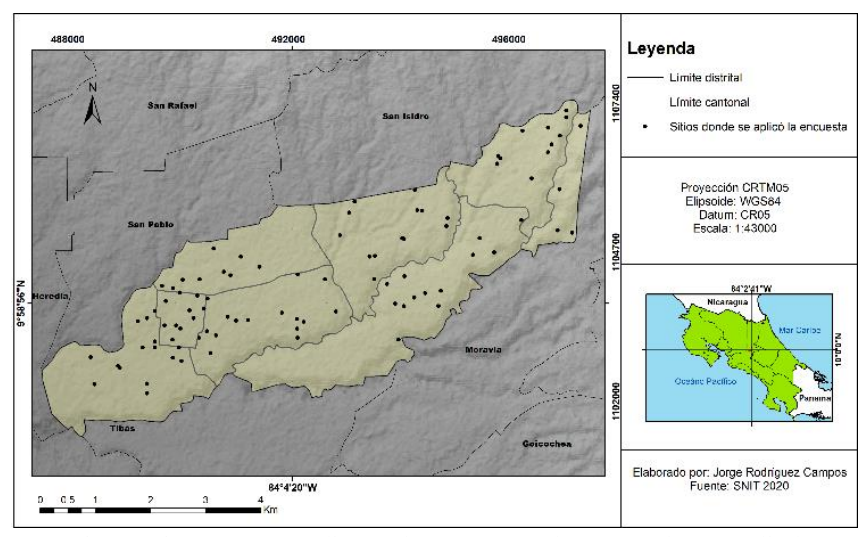

Fig. 2. Sites corresponding to houses were the researchers applied the instrument to know the educational level on risk management of the Civil Society.

The research group asked the individuals about access to information on risk management of the canton, main hazards, causes of emergencies and courses received to manage the risks of Santo Domingo efficiently. Regarding access to the information, this category included the following subcategories: bad, regular, good, very good, excellent, and I don't know (DN)/ don't respond (DR). A $57 \%$ of the interviewees indicated that their access to the information is bad, $25 \%$ considered it regular and only $1 \%$ stated that such access is excellent. Those who consider the access good $(10 \%)$ are people who receive information from WhatsApp groups or work at the City Hall, where they have more information on risks and disasters. In the area of Para, 9 out of 13 people stated that they have regular access to information on risk management, but this is because most of them are members of the Asociación de Desarrollo Comunal (Communal Association for Development) and therefore, they are better informed about threats, vulnerabilities and risks of the district and the canton.

The main perceived dangers in order of importance are floods, assaults, traffic accidents, landslides and fires. Other perceived threats include pipeline fuel leaks, tornadoes, earthquakes, lightning, falling trees, droughts, volcanic eruptions, and hurricanes. According to the interviewees, in the Central and Santo Tomás districts floods are frequent, and robbery is a very common danger in Santa Rosa. Traffic accidents are clearly perceived as one of the main reasons of concerns in Santo Tomás, San Vicente and Pará. Interviewees from Pará said that crossing the Route 32 is a real hazard.

Regarding the origin of emergencies, the main cause perceived by the population is floodings, followed by traffic accidents and landslides. Interestingly, among other causes, people also mentioned the traffic jams, water chlorination, lack of disaster's prevention, irresponsible behavior, climate change, deforestation, lack of planning, sewer capacity, water and environmental pollution, hurricanes, lightning, social insecurity, roadside infrastructure, roadside signaling, lack of information on risks, water supply, negative behavior habits, solid waste, building permits, water channeling, monitoring to the projects and rooming houses.

To find out the knowledge transferred by members of the local emergency committees, especially the Municipal Emergency Committee, to the members of the community the researchers asked the participants whether they have received courses on risk management. The number of responses by district is shown in Fig. 3.

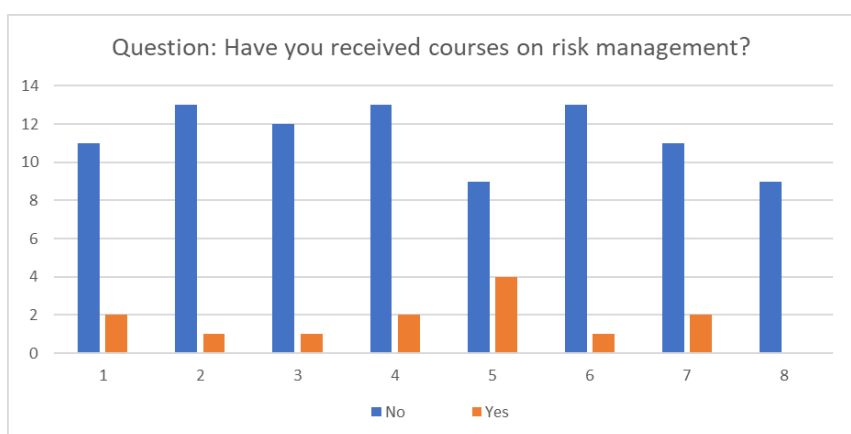

Fig. 3. Answers to questions on preparedness received to manage the risk. The districts are: 1: Santa Rosa, 2: Central, 3: San Vicente, 4: Santo Tomás, 5: Tures, 6: San Miguel, 7: Pará, 8: Paracito.

According to the answers, Santo Domingo's society has not been adequately prepared to manage its risks. An $88 \%$ of the interviewees stated that they had not received training to manage the canton's risks, while $12 \%$ expressed that they had received some capacitation or courses related to risk management (Fig. 4). Of the 13 individuals who have received training, 3 acquired the information in community committees, 3 at school and 2 at the workplace. Such results reveal a sporadic training that does not respond to permanent processes of capacitation organized by the local risk managers. No matter that, the society is slowly acquiring more information on the risks and some preparation to face them. Social networks and organized groups are playing a very important role in managing emergencies and disasters. Although little is being done, the population's preparation is increasing.

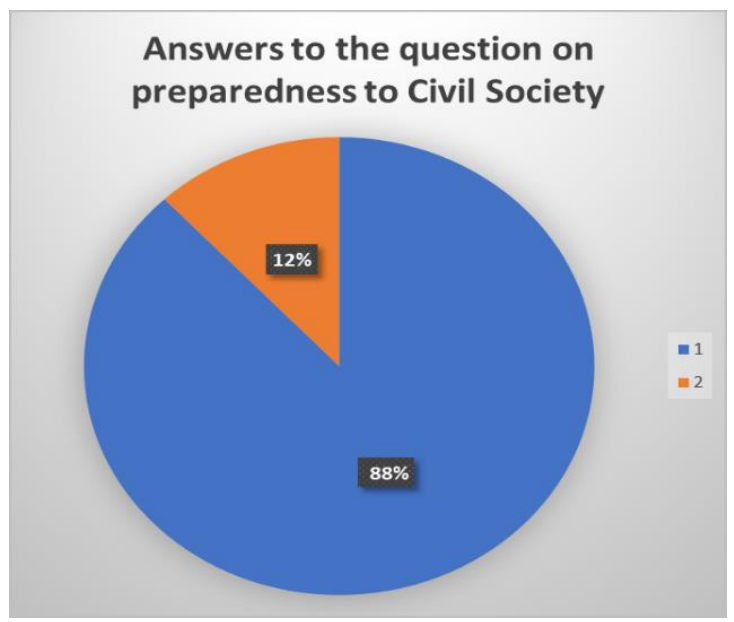

Fig. 4. Percentage of answers.

1: No preparation, 2: Preparation received. 
A total of 12 people from the sample were under 21 years of age and only 3 of them indicated that they have received training to better manage risks. This result suggests that, in general, the young group of the population is not better prepared to face hazards than the adult group. The research group supposed that young people are better prepared than adults by recent training received in schools and colleges, but according to the interviewees that is not the reality. From this result, the researchers concluded that training for risk management in schools and colleges is not incidental and must be improved.

\section{CONCLUSIONS}

The Municipal Emergency Committee of Santo Domingo has received training on disaster management, management of communications, supply management system, damage evaluation and incidents command system from the National Commission for Risk Prevention and Emergency Attention (CNE). Some teachers from elementary schools have basic training in first aid and the use of fire extinguishers, and something similar occurs in public institutions where workers have taken courses on fire hazards, damage evaluation, incidents command and some specialized courses of the health area such as Cardiopulmonary resuscitation (CPR), bandage and stretcher. Civil Society receives practically no preparation for risk management; $88 \%$ of the sample said they had not received training on it. According to the results, the capacitation on risk management to the different groups investigated is very basic and more focused on response than prevention and is not helping to understand risk in all its dimensions of vulnerability, capacity, and characteristics of hazards.

Schools teaching staff has received little training on risk management. They have taken mainly courses on first aids. However, they said that teaching on that subject is easy for them. On the other hand, in almost all the educational centers visited the risk managers carry out evacuation exercises.

In terms of response, all the consulted entities are prepared through simulations, drills and evacuation signaling. Risk management plans are made in schools, but those who prepare them are not sure that they are well done.

\section{REFERENCES}

[1] Fernández, M., Borges, J., Meléndez, G., Mora, F., Mora, J., Muñoz, Ch., 2013: Análisis de Gestión de Riesgo de Inundación en la ciudad de Santo Domingo de Heredia, en Adamson, M., Castillo, F.: Costa Rica en el tercer milenio: desafíos y propuestas para la reducción de vulnerabilidad ante los desastres.

[2] Reyes, J., Fernández, M., 2013: Amenazas Tecnológicas en Santo Domingo de Heredia, Revista de Salud Ocupacional HOY, octubre.

[3] Reyes, J., Fernández, M., 2014: Landslide Potential in Santo Domingo De Heredia, Costa Rica, Central America. Journal of Geography and Geology; Vol. 6, No. 4, ISSN 1916-9779 E-ISSN 1916-9787.

[4] Reyes, J., Fernández, M., Grinesky, S., Collins, T., 2014a: Natural Hazards in Santo Domingo de Heredia, Costa Rica, Central América. Natural Science. Vol.6, No.3, 121-129.

[5] Rojas, M., Fernández, M., 2016: Volcanic Deposits and Volcanic Hazard in Santo Domingo de Heredia, Costa Rica. Journal of Geography and Geology; Vol. 8, No. 2; 111-126, doi:10.5539/jgg.v8n2p111.

[6] Fernández, M., Calderón, A, Bolaños, R., 2019: Avances en la estimación del riesgo sísmico del cantón Santo Domingo de Heredia. Revista Geológica de América Central, 60, 123-131, 2019 doi: 10.15517/rgac.v2019i60.36467, ISSN: 0256-7024.

[7] Reyes, J., Fernández, M., Solís, D., Villalobos, R., 2014b: Assessment of Physical Vulnerability in Santo Domingo De Heredia, Costa Rica, Central America. World Journal of Engineering and Technology, 2014, 2, 78-84.

[8] Reyes, J., Fernández, M., 2015: Máxima Vulnerabilidad Humana en Santo Domingo de Heredia. Rev. Reflexiones 94 (1): 37-47, ISSN: 1021-1209.

[9] Comisión Nacional de Prevención de Riesgos y Atención de Emergencias - CNE (2014). Estrategia para la Gestión del Riesgo de Desastre en el Sector Educación de la República de Costa Rica, 48 pgs.

[10] Comisión Nacional de Prevención de Riesgos y Atención de Emergencias - CNE (2013). Guía para la elaboración de planes de gestión del riesgo en centros educativos.

[11] UNICEF, 2010: Índice de Seguridad Escolar (ISE), 76 pgs. 